\title{
Application of Technology Solutions during the Covid-19 Crisis: Latin America's 50 Best Restaurants
}

Pareti S.

Universidad Andrés Bello, s.pareti@uandresbello.edu

Monllor J.

Oxford Brookes University, jmonllor@brookes.ac.uk

Kraft I.

Pontificia Universidad Católica de Chile, i.kraftgutierrez@gmail.com

The main objective of this work is to explore how ventures have adapted their commercial proposals after the changes brought upon by Covid-19. We selected The Latin America's 50 Best Restaurants list as a case study, (1) due to it being an international ranking that unifies and selects the best restaurants in a specific geographic sector, (2) each of the restaurants in the list have a tradition of providing a service that is consumed or experienced locally as it allows them to control all aspects of the dining experience, (3) prior to the Covid-19 pandemic, given the differentiated offer of products offered by each restaurant, the restaurants did not work with food delivery applications (4) prior to the Covid-19 pandemic, their menus were printed on paper and not in a digital format through the use of mobile technology, (5) the preparations and presentations offered prior to the Covid-19 pandemic were intended for consumption at the point of sale service and not delivery. To conduct the study, an analysis was carried out, comparing various variables that subsequently made it possible to assess whether mobile technologies were opportunities to the ventures in our sample. We found that the offerings of this type of restaurants had to adapt to the new scenario, moving from seeing mobile technology as a simple marketing tool to a new commercial ally, adapting to the needs of each of these technologies and therefore adapting their respective product mix and packaging.

CCS CONCEPTS • Latin America's 50 Best Restaurants • Gastronomic \& Culinary Marketing

- Mobile Technology \& covid-19

Additional Keywords and Phrases: Gastronomic experience marketing, tic`s y gastronomy ACM Reference Format: 


\section{Introduction}

With the arrival of the Covid-19 pandemic, various governments around the world have been forced to implement confinement measures, where commercial premises, in this specific case restaurants, due to legal restrictions, could not open their doors to conduct business and service their clients. While an obligation for all, this can represent an opportunity for some of these types of businesses to seek new ways to reach consumers and prosper.

Marketing has also had to adapt to the new era of Covid-19, where changes in consumer behavior are occurring (Hoekstra \& Leeflang, 2020). Some specific examples of the new strategies implemented in response to the pandemic have been launching new service offerings and introducing new elements to existing service offerings, fostering social relationship with customers, exploring novel streams of revenue, and reinvigorating the brand's image (Tuomi, Tussyadiah \& Ashton, 2021).

Gastronomic tourism has its roots in local culture and is used as an opportunity to increase tourism, as it reflects each region and its culture. There is a particular group of tourists who are heavily influenced by the gastronomy of different restaurants that focus on enhancing the flavor and ingredients of their local food (Hernández \& Dancausa, 2018). The negative impact on the gastronomic industry by the Covid-19 pandemic has been amplified by the global decline in tourism, both of which are closely linked. Social distancing and the restriction measures implemented by each country have been the main causes for this chain reaction (Gossling, Scott \& Hall, 2020; Kim, Kim \& Wang, 2021). On the other hand, based on the measures imposed and the risks of contagion, consumers have also developed apprehensions regarding the consumption of products outside the home, being cautious about contact with others and the products that are delivered from restaurants to their home due to the possible risk of contagion (Byrd et al, 2021).

It is for these reasons that restaurants have had to adapt to the new realities presented to their industry, putting special emphasis on hygiene and safety (Lakshmi \& Shareena, 2020) and in some cases going as far as having to pivot and completely modify their business models (Norris, Taylor \& Taylor, 2021),. The use of technology and mobile technologies has also become a new way to stay active in the market, linking it to an organizational redesign and focusing on efforts of collaboration, creativity, and innovation to generate social contagion, digital transformation, and increased speed of adoption of these new proposals (George, Lakhani and Puranam, 2020). The adaptation mechanisms to engage with the consumer under the pandemic have had care and concern as their focus, meeting customers 
where they are, reimagining a post-Covid world and building agile capabilities for fluid times (Diebner, Silliman, Ungerman \& Vancauwenberge, 2020).

Although the confinement measures for many businesses can represent a nuisance, for others, Covid-19 and the pandemic can be considered an opportunity (Monllor \& Altay, 2016; Monllor \& Murphy, 2017) to transform their business and the gastronomy industry, considering major tourism stakeholders (namely tourism demand, supply and destination management organizations and policy makers) in their new plans and taking a comprehensive look at the response, recovery and reset of the industry (Sigala, 2020). Social media marketing, which exists thanks to mobile technologies, has become very important when buying a gastronomic product (Mason, Narcum \& Mason, 2020). Covid-19 is directly linked to hospitality marketing and management scholars' research agenda, especially considering it is a field in the early stages of developing its research and the questions it wishes to answer (Gursoy \& Chi, 2020) and thus presents great development opportunities (Peistikou, 2020).

This research makes an initial approach toward expanding our knowledge of the gastronomic industry and its use of technologyunder Covid-19, with special emphasis in Latin America, Our main objective is to investigate whether mobile technologies represent an opportunity or a threat. The list of Latin America's 50 Best Restaurants was selected because: (1) it is considered an international ranking that unifies and selects the best restaurants in a specific geographic sector, (2) each of the restaurants in the list have a tradition of providing a service that is consumed or experienced locally as it allows them to control all aspects of the dining experience and (3) prior to the Covid-19 pandemic, given the differentiated offer of products of each restaurant, the restaurants did not work with food delivery applications (4) prior to the Covid-19 pandemic, their menus were printed on paper and not in a digital format through the use of mobile technology, (5) the preparations and presentations offered prior to the Covid-19 pandemic were intended for consumption at the point of sale service and not delivery, (6) all the restaurants in the ranking, beyond just offering high-quality products and services, focus on providing an extraordinary consumer experience (Green, 2020).

The article is organized as follows: first we conducted a literature review on gastronomic marketing, experiential marketing in gastronomy and, information technology and gastronomy. Next, we explain and develop our research methodology and the results of the study are presented. Finally, the conclusions of the study are drawn up, detailing how these restaurants, adopted mobile technology and saw it as an opportunity during the Covid-19 pandemic.

\subsection{America's 50 Best Restaurants}

America's 50 Best Restaurants is a prestigious list created as an alternative to other types of rankings such as the Michelin Guide, for example (William Reed Business Media, 2021). The 
list is compiled by a highly influential group of 250 critics from the Academy of the 50 best restaurants (not chefs) in Latin America (William Reed Business Media, 2021). The Academy is composed by judges who are chosen to select and recognize the 50 Best Restaurants in Latin America based on their expertise in gastronomy. This list was launched in 2013 to celebrate gastronomy and provide customers and diners with different knowledge and culinary recommendations. This Academy covers several countries, among, among them are Argentina, Belize, Bolivia, Brazil, Chile, Colombia, Costa Rica, Ecuador, El Salvador, French Guiana, Guatemala, Guyana, Honduras, Mexico, Nicaragua, Panama, Paraguay, Peru, Suriname, Uruguay, and Venezuela. The list is published by William Reed Business Media, who also launched a program in May 2020, during a pandemic, that supports restaurants around the world, providing financial aid, valuable resources, advice, and support (William Reed Business Media, 2021).

The modality that is used for this list does not have specific requirements. Each chosen judge is asked to list ten restaurants from Latin America in order of preference (six of which must be from the expert's region and four from a different region). The expert must have visited the place less than 18 months prior (the date of the last visit must be confirmed) and they cannot vote for restaurants that are closed or are only temporary. There is no style, size, or any special feature by which they should be guided. Obviously, experts cannot be involved with the restaurants they are selecting and must remain anonymous with their vote to stay in the voting pool (William Reed Business Media, 2021).

\subsection{Food Experience Marketing}

One of the key objectives for brand managers is to deliver an unforgettable and memorable experience to customers and thus maintain a positive customer-brand relationship. Recent years have seen an explosion in the number of product options available for customers, along with competition among those who deliver these products and services. This leads to consumers with greater decision-making power that are concerned with choosing brands that deliver memorable and unique experiences and not only physical and functional aspects (Wiedmann et al, 2017). Another consequence is that consumers are demanding more and more quality in what they consume and in how they are served (Quan \& Wang, 2004), leading to the advent of a new point of view in which, through interaction, customers build their own consumer experience, creating additional value. This is considered by some to be one of the greatest benefits perceived by customers (Rather, 2019) and for this reason the concept "Experiential Marketing" has been gaining ground (Wiedmann et al, 2017). Its main use being to stimulate people sensorially and symbolically, making them experience emotional and imaginative responses in the decision-making process (Le, Scott \& Lohmann, 2018). The experience of the consumer has taken center stage in economic and social life, gaining special strength in the tourism industry where gastronomy is significantly embedded. While experiential marketing can deliver important experiences to gastronomy 
customers, whether the product (food) or the experience is the highlight of the interaction, or an complement is not yet clear. What is clear is that consuming food and beverages is a unique experience that has led to its emergence as a new form of tourism that includes gastronomic tourism (eg. "Wine Tour in Europe") and gastronomic festivals (Chocolate Festival in Suffern, NY), among others (Quan \& Wang, 2004).

The Online School of Gastronomic Marketing (Silva, 2020) states that for a memorable experience to be created and maintained, businesses must look at differentiating themselves from the competition through a bundle of products, packaging, promotions, and communication with the customer. Many high-end restaurants have adopted these recommendations to maintain and create gastronomic experiences for their customers and set themselves above the fray. As a response to the changes brought upon by the pandemic have been forced to adapt their products and systems, with menus presented in ideal formats for dispatch (delivery), adapting meals meant to be served in the restaurant to ready-totake/ship meals that are meant to be consumed immediately or vacuum sealed products that can be refrigerated or frozen for later consumption. They have also provided options to translate the consumer experience to the home by creating menus that allow for wine tasting experiences and even music playlists created in the Spotify music application to accompany the meals. Demo for example, a Finnish restaurant, created a menu that could be put together at home using an instructional video (Tuomi et al, 2021). Certain food establishments have reduced their menu options to allow for easy and quick preparation of dishes, while maintaining a good appearance and arriving in good condition (Álvarez et al, 2020). Another example is provided by a company called "City Tasting Tours", which has created a platform to carry out virtual gastronomic tours in the city of Memphis, Tennessee (USA), along with food delivery to the people who participate. The owners of the restaurants tell the history of the establishments included in the tour, talk about the local gastronomy and traditions. These are available in private, or with groups of people who are watching from the comfort of their homes (City Tasting Tours, 2020).

\subsection{Gastronomic marketing}

Gastronomic marketing is defined as "a set of actions that transmit an idea, the purpose of which is to surprise and satisfy the needs of customers with the food they produce". This is accomplished through what we know as advertising or marketing, through the image they create, they transmit that they are different and better than the rest in some specific way (Álvarez et al, 2020). Food marketing and advertising can be a real empowering opportunity for food producers, restaurants, and farmers, where they can add value to their products and achieve great growth (Quan \& Wang, 2004). It allows for the demonstration of the different flavors and tastes that a particular society has, along with its culture, especially if they have the benefit of a wide variety of products and the potential for their location becoming a tourist destination, proposing new perspectives towards what the identity of a region is 
(Espinoza, 2020). In this case, gastronomic events are a great tool to highlight the local identity of the place where the event is taking place and holds the possibility to involve the local community, making gastronomic tourism into something sustainable (Quan \& Wang, 2004).

In recent years, the use of the internet has allowed marketers to have greater contact with their target or customers and it has become a useful tool when wanting increased exposure. A website is considered by most restaurants as a necessity, in conjunction with a presence on Instagram, Facebook, Tik-tok and many other social media platforms. For example, websites are used by customers to select the restaurants they are going to visit on trips (Miranda et al, 2015). Publishing information regarding their dishes, new creations and promotions has helped restaurants stay active and continue to attract customers. The creation of new delivery formats and plate formats have been key to attracting the attention of customers and being able to survive in the face of the current health crisis (Avraham, 2020).

It is clearly becoming apparent that gastronomic marketing has had to modify its way of operating and rethink its business model due to the changes brought upon by the Covid-19 pandemic that has impacted the world, both in economic and health aspects (Paredes et al, 2020). People have had to maintain social distancing and stay in their homes, which limits travel, and directly incurs a hard blow for restaurants that make a living from tourism (Garibaldi \& Pozzi, 2020). There are various methods of advertising for restaurants to make themselves known, such as email marketing, which is very effective and easy to handle. There are transactional emails, which are commenced thanks to the previous interaction of a customer with the restaurant's website once they input their email to execute a purchase, receive some benefit or notifications of new offers. Marketing through the website is also essential, where, to acquire and retain customers, businesses must make sure to have welldistributed and frequently updated information along with a well-designed website. A key point in gastronomic marketing is customer service, which requires constantly improvement, knowledge of customers' needs and an understanding of what makes them remain in contact. In addition, delivering a unique experience through branding, which begins with advertising, fonts and graphics design and results in delivering good food. Photographs on social networks are also very important to attract the attention of potential customers or retain customers loyalty (Álvarez et al, 2020; Silva, 2020).

Macchiavelli (2020) posits that everything that tourism entails, along with what the different companies will have to do, will be different after the pandemic. This presents a difficult situation for local restaurants and businesses, since many are managed by, employ and are supported by people who live in the community. To many, these businesses are their main sources of and it is important that gastronomic marketing has a sustainable outlook, ensuring their longevity, and providing support to the families and communities of those involved. 


\subsection{Information technologies and gastronomy}

Thanks to globalization and the constant technological advances that the world is witnessing, people, organizations and diverse actors are experiencing a faster and more dynamic context (García-Álvarez, 2013). Information technologies (ICTs) refer to the study, design and management of information systems that are solely based on computers. They are tools utilized by people to provide and facilitate access to digital platforms and data. It has been seen that ICTs have benefited learning in the processes of creation and transmission of knowledge (García-Álvarez, 2013) and more attention is being paid to the application of new technologies and artificial intelligence (Zabin, 2019).

The world is in constant flux given globalization, technology, urbanization, and an aging population (Dobbs et al, 2015), and these factors are further exacerbated by unexpected or unplanned events, such as the Covid-19 pandemic (Taleb, 2008). This surprise event had an especially large impact on the hospitality industry, specifically in the restaurant sector, who are under intense pressure, with many having to adapt to increased sanitary measures, while others have had to close their doors completely. In the "best" of cases, adapting premises so that the necessary social distancing requirements are met was enough, but this has led to a decrease in capacity by more than $80 \%$ (Nhamo et al, 2020). Other impacted aspects are the reduction of workers and operations, the redefinition of competitive advantages and pivoting the business model (Bajwa et al, 2017). Technology serves as a great tool in the restaurant industry to help promote the transmission of information and promotions to customers (Garibaldi \& Pozzi, 2020). ICTs have become especially relevant in the gastronomy industry for communication and to be able to innovate when service is adapted for take-out, at home or remote service (Tuomi et al, 2021).

Tuomi et al. (2021) indicate that technological applications, web systems or mobile applications have been widely used as communication channels for restaurants during the pandemic period. They highlight that in 2019 , Instagram posts by these restaurants were merely promotional, but in 2020 they had transitioned to more educational content, focused on new and dyadic ways of offering their products. Instagram especially became the most important means of maintaining contact with customers. Technology has not only helped restaurants continue functioning but has also allowed them to develop very creative ways to approach their customers (Tuomi et al, 2021). Providers have taken the initiative and have developed ideas to solve their new problems: from delivering remote meal experiences through video calls, to online cooking classes, talks and courses among some examples (Garibaldi \& Pozzo, 2020). Finnjävel, a Finnish restaurant, offered customers the possibility of participating in an online course that provides tools focused on taking care of people's mental health in periods of Covid-19. Savoy, another Finnish restaurant, took the opportunity to educate its followers about its beginnings and history, while $\mathrm{C}$, yet another restaurant in Finland, communicated how important it is to work with local suppliers in difficult times, where global supply chains are negatively impacted (Tuomi et al, 2021). 
Digital platforms, and mobile technologies are a good opportunity for restaurants, and other organizations, to improve their business and not get left behind, given the negative impact that is the pandemic. They are also a good solution for customers where they can choose the products they want and, at the same time, access the status of their order in real time through online and mobile applications. In addition, since social distancing is a very effective way to slow the spread of the virus, digital technologies are a great opportunity to innovate and differentiate yourself as a company (Seyitoglu \& Ivanov, 2020). Many food companies for example, took the pandemic as an opportunity to change or improve their business models (Tuomi et al, 2021).

\section{METHODOLOGY AND RESULTS}

The research methodology was developed considering different perspectives. First, we obtained the latest list of the Top 50 restaurants (Table 1) and proceeded to find and analyze the official website and Instagram accounts of each. We then proceeded to compile, analyze, and compare the following data: restaurant name, status (open or closed), availability of online sales, in-store pick-up, ready-to-serve preparations and/or vacuum sealing options. We also analyzed adaptations in food packaging for online sales, opening of new businesses (such as selling merchandise, ingredients, produce or pickled products, etc.), and special Covid-19 promotions (simple changes in packaging notwithstanding).

It should be noted that to carry out the Instagram social network analysis, we limited the timeframe from February 2020 to February 2021. This period was selected to include in the analysis a comparison points from right before the start of the Covid-19 pandemic.

Table 1: List of the Latin America's 50 best restaurants 2020.

\begin{tabular}{|c|c|c|}
\hline $\begin{array}{l}\text { 1. Don Julio, Buenos Aires (best restaurant in } \\
\text { argentina) }\end{array}$ & $\begin{array}{l}\text { 17. Sud } 777 \text {, Mexico City } \\
\text { 18. Kjolle, Lima }\end{array}$ & $\begin{array}{l}\text { 36. Máximo Bistrot, Buenos } \\
\text { Aires }\end{array}$ \\
\hline 2. Maido, Lima (best restaurant in Peru) & 19. Chila, Buenos Aires & 37. Mérito, Lima (Aspire highest \\
\hline 3. Central, Lima (Gin Mare Art of Hospitality & 20. Isolina, Lima & new entry) \\
\hline award) & 21. Lasai, Rio de Janeiro & 38. Osaka, Buenos Aires \\
\hline 4. A casa do porco, São Paulo (best restaurant in & 22. Astrid y Gastón, Lima & 39. Elbaqueano, Buenos Aires \\
\hline Brazil) & 23. Maní, São Paulo & 40. Narda Comedor, Buenos \\
\hline 5 Pujol, Mexico City (best restaurant in Mexico + & 24. Mayta, Lima (Illy Highest & Aires \\
\hline $\begin{array}{l}\text { Flor de Caña award for best sustainable } \\
\text { restaurant) }\end{array}$ & $\begin{array}{l}\text { Climber) } \\
\text { 25. Harry Sasson, Bogotá }\end{array}$ & $\begin{array}{l}\text { 41. Restaurant 040, Santiago de } \\
\text { Chile }\end{array}$ \\
\hline $\begin{array}{l}\text { 6. Boragó, Santiago de Chile (best restaurant in } \\
\text { Chile) }\end{array}$ & $\begin{array}{l}\text { 26. Evvai, São Paulo } \\
\text { 27. Leo, Bogotá }\end{array}$ & $\begin{array}{l}\text { 42. Maito, Panama City (best } \\
\text { restaurant in Panama) }\end{array}$ \\
\hline 7. El Chato, Bogotà (best restaurant in Colombia) & 28. Parador La Huella, & 43. Aramburu, Buenos Aires \\
\hline 8. Mishiguene, Buenos Aires & Maldonado (best restaurant in & 44. Manu, Curitiba \\
\hline 9. Roseta, Mexico City & Uruguay) & 45. La mar, Lima \\
\hline 10. Osso, Lima & 29. Rafael, Lima & 46. Ambrosía, Santiago, Chile \\
\hline 11. Quintonil, Mexico City & 30. Le Chique, Cancun & 47. Palermo's, Buenos Aires \\
\hline 12. Oteque, Rio de Janeiro & 31. Nicos, Mexico City & (new participant) \\
\hline 13. DOM, São Paulo & 32. De Patio, Santiago de Chile & \\
\hline
\end{tabular}




\begin{tabular}{lll} 
14. Pangea, Monterrey & 33. Mocotó, São Paulo & favorite48. Nuema, Quito (best \\
15. Mayor, Guadalajara & 34. Gran Dabbang, Buenos Aires & restaurant in Ecuador) \\
16. Tegui, Buenos Aires & 35. MIL, Cusco & $\begin{array}{l}\text { 49. Celele, Cartagena (new } \\
\text { participant) } \\
\text { 50. Corrutela, São Paulo (new } \\
\text { participant) }\end{array}$ \\
\hline
\end{tabular}

Source: Own construction adapted from Fine Dining Lovers, 2020.

The results from our analysis indicate that the countries with the greatest presence in the list of the 50 best restaurants are Argentina and Peru, with 11 restaurants each, followed by Brazil and Mexico, with 9 restaurants each, then Chile with 4 restaurants, Colombia with 3 and finally Ecuador, Uruguay, and Panama with one restaurant each. Two restaurants had closed in response to the pandemic at the time of our study. These are MIL in Cusco, Peru, and De Patio in Santiago de Chile. Both indicated in their respective communication channels (Instagram and website) that they planned to reopen sometime in the future and De Patio had opened a new location, De Calle, that is not included in the ranking. Most restaurants $(72 \%)$ on the list are currently serving both in person and through online dispatch (Figure 1).

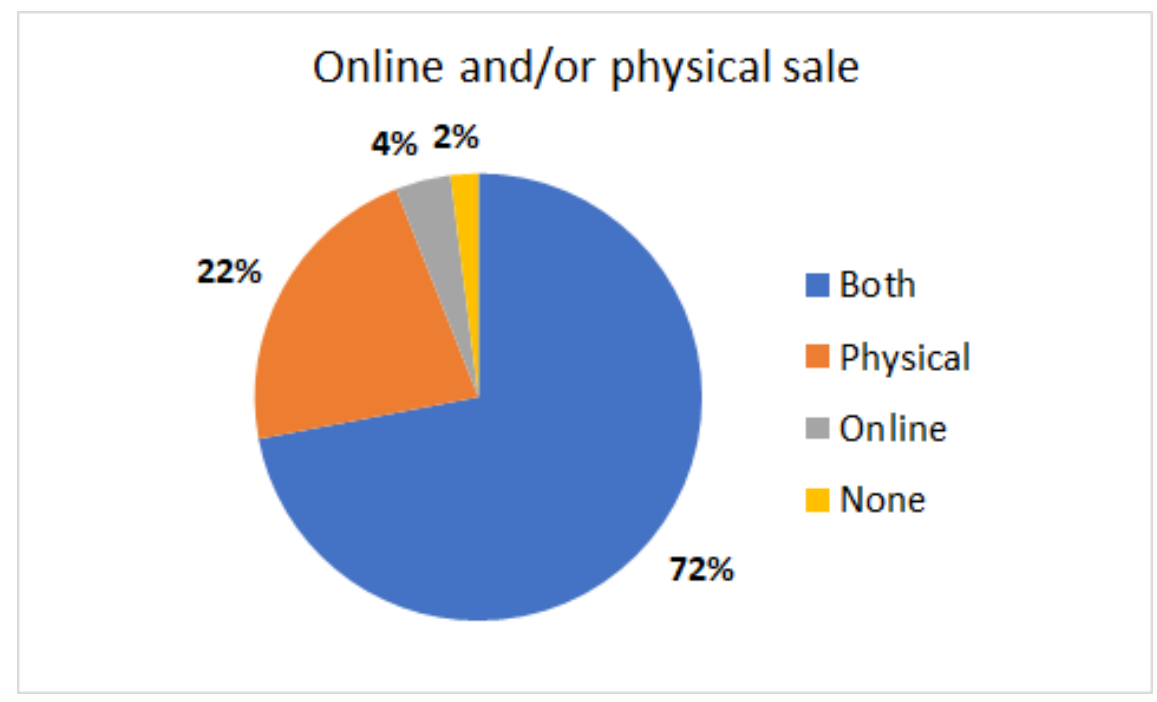

Figure 1: Percentage of restaurants and their type of operating in the pandemic. Source: Own construction.

Figure 1 also shows that most restaurants are operating both online and in person. Considering that for these restaurants the customer experience is based not only on food but also on the physical space, several have had to create spaces for their new delivery and online sales models. It was observed that these restaurants have made changes in their packaging and have partnered themselves with various mobile applications and generating 
new ways to generate income. One popular modality is the use of vacuum sealed products. Given the experiential component that these restaurants provide, relying on third applications runs the risk of inferior quality and a diminished experience when compared to the standards set before the pandemic when they could control all aspects of their service. For this reason, vacuum sealed products have become a popular option as it transfers the experience to the home where the consumer creates their own experience.

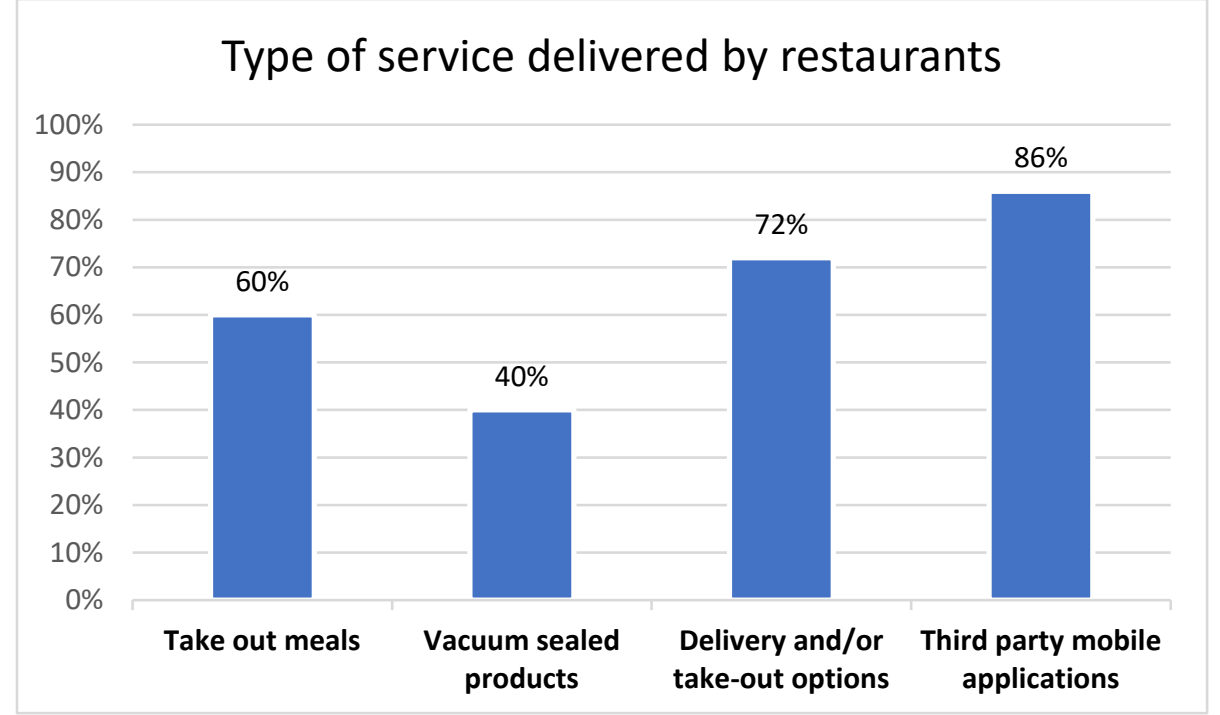

Figure 2: Percentage of restaurants and their type of service in the pandemic. Source: Own construction.

Figure 2 shows the type of service by restaurants. Regarding the business models used by the restaurants in the sample, $60 \%$ provide take-out meals solely, while another $40 \%$ have started providing vacuum sealed products that can be stored at home for later preparation, in addition to take-out. $72 \%$ of the restaurants in the ranking offer delivery and/or take-out options. These all sell directly from their respective websites, providing the service out of their own locations or using mobile applications. The percentage of restaurants that rely on third party mobile applications such as Rappi, UberEats and Glovo, corresponds to 86\%.

In terms of packaging, $56 \%$ of the stores have had to make changes to be able to adapt their offering to the requirements of online sales and subsequent delivery (Figure 3). It was easy to appreciate the lengths these establishments went through to modify and provide new packaging. Aramburú (Argentina 44th), Ambrosía (Chile 46th), Astrid y Gastón (Perú 23rd), Casa do Porco (Brasil 4th), Osso (Perú 10th), Cebichería La Mar (Peru 45th) y Lasai (Brasil 21st) are some of the restaurants on the list that created new packaging options (Figure 3). 
Packaging adapted for delvery format. for father's day- -Aramburu. (Argentina)

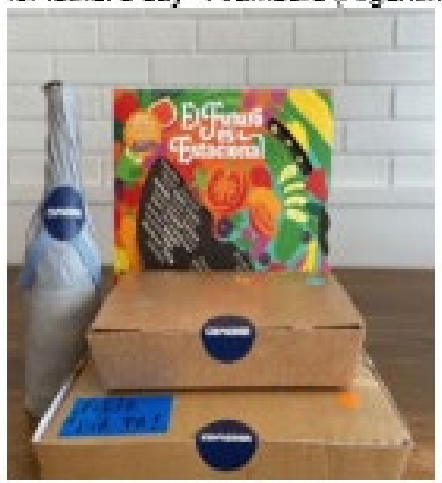

Box packaging adapted for delivery. format:-Aramburu-(Argentina)

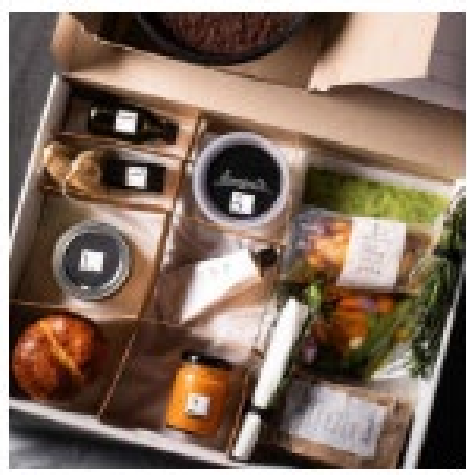

Promotion generated for orders through third party delivery app Rappi $\cdots$ Isolina:(Perú)

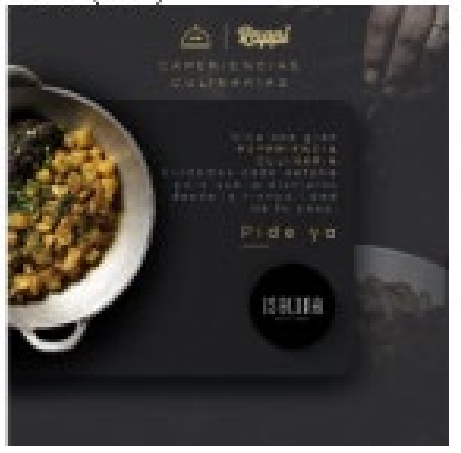

Packaging; adapted for delvery format - Cebichería-La-Mar(Peru)

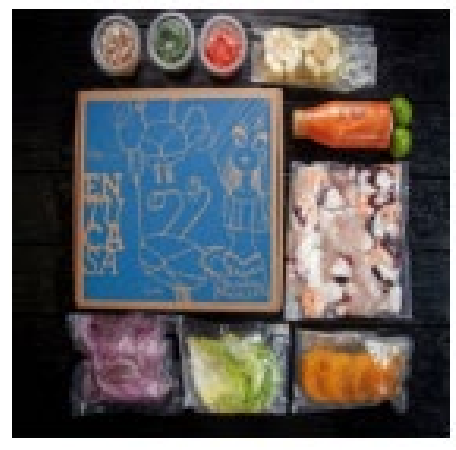

Box packaging adapted for Christm: delivery format--Lasai'(Brasi)

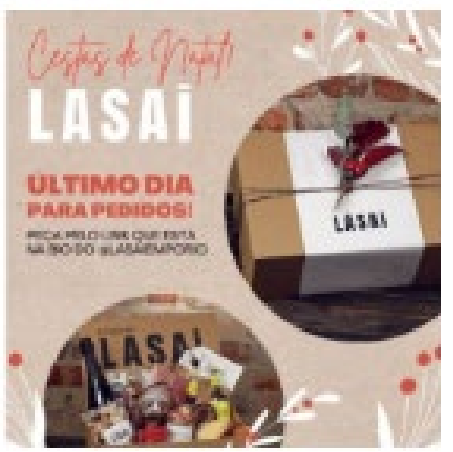

Figure 3: Packaging and presentation examples developed by restaurants to adapt to home delivery format. 
Finally, in relation to social networks, all restaurants on the list have a profile on Instagram social network. 92\% constantly use Instagram to communicate with their target market, while the remaining $8 \%$ have published photos, stories, or others with very low frequency. Unfortunately, our study was unable to gather enough data regarding the use of promotions and gift cards as there is very little reliable information on the restaurants' social media platforms. Only two of the restaurants in the list were found to provide some sort of promotion related to the Covid-19 pandemic. Maido (Peru), while currently closed, still posted an offer on their social media in which they promoted the creation of a new shorter and cheaper menu (Agencia EFE, 2020). Restaurante 040 (Chile) is the other restaurant which used promotions on social media (Greve, 2020).

Some restaurants realized that running their establishments as usual was not sustainable thus they decided to create new offerings and try new business models. De Patio (Chile), for example, is a restaurant which had to close its door until further notice but proceeded to open another restaurant called "Ramen and Burgers". Borago's (Chile) owner, Rodolfo Guzman, created "Muumami", a brand specializing in a 100\% vegetarian burger and ice cream with innovative flavors. These two demonstrate the capacity of many of the restaurants to innovate when confronted with a difficult situation by pivoting, placing their original restaurant on hold, and attempting to keep it afloat by running a side business. Many of the chefs from restaurants in the list also decided to stay at home but continue to work on side projects and ideas. Chefs from Mishiguene (Buenos Aires), Boragó (Santiago, Chile), La Huella (Uruguay) and Baqueano (Buenos Aires) are some examples, with their chefs working writing and launching recipe books that are available to download online (Greve, 2020).

\section{Discussion}

Due to the new scenario brought upon by the Covid-19 pandemic the market has had to adapt to new challenges and needs, changing their working strategies to remain competitive. While all industries have been heavily impacted, according to the United Nations (United Nations, 2020), tourism and gastronomy have felt some of the heaviest burden. It is for this reason that one of the opportunities created by the new scenario has been to strengthen sales channels, such as online sales with new products, or new ways to distribute current products for home consumption.

Before the pandemic not all restaurants possessed online sales systems, so online technologies became an opportunity for those who had not incurred in this modality and to further hone and develop their models to those that had already set up such practices. The only restaurant that does not work with delivery nor take outs services is MIL (35th) in Cusco, Peru. For some, opening new restaurants that were better adapted to the current situation was a requirement, but their strategies were not included in the study as they were not part of the Top 50 Restaurants list selected for our sample. 
In a recent news article (Greve, 2020) that interviewed some of the restaurants on the lists, we can see brushstrokes of the effect the pandemic has had on these top restaurants and the industry and similarities between his article and our results. 49 of the restaurants in the Top 50 ranking have adopted a take-out business model. Greve (2020) found that various restaurants attempted to switch to food delivery at the beginning of the implementation of lockdown measures, but this was not sustainable for some. De Patio (32nd) who has been running since 2016 and was forced to wait until things settled and they had access to reliable information and stability. Ambrosia, in Santiago de Chile, was forced to close in the first days of confinement (16th March) until further notice, but it reopened shortly after with delivery and take out service. It is also possible that customers felt it was not safe to venture outside or consume food items that were prepared outside the home due to the lack of information regarding transmissibility of the virus through contact or coming in close contact with delivery employees.

The current study analyzes whether technology solutions during the Covid-19 pandemic result in an opportunity or menace. To accomplish this, we selected to compare those actions taken by restaurants who have been selected as Latin America's Top 50 restaurants. By selecting these establishments, we intended to provide the study with a homogenous yet internationally recognized sample. These restaurants are all also recognized for placing special attention on the service experience that was specially developed to be provided in person and in a physical environment. Thus, by focusing on them, we were able to understand how these had to adapt to the new realities experienced under the pandemic crisis, by adopting new ideas, business models and services that would not normally be possible or considered in the past.

\section{Conclusion}

The current study makes an important contribution as it analyzes adaptation strategies by one of the most impacted industries when confronted by a significant crisis. Simultaneously, it examines how the experiential component of the service can be maintained with new practices of developing their product or service offerings.

We observed that when launching concrete strategies consisting of changes in packaging, offering product delivery options, adapting product presentations from ready to consume to vacuum sealed and ensuring that the experience remains unaffected, it led to new modes of relating with the market and helping these businesses survive the pandemic. Some restaurants in our study went further, by innovating and pivoting to new business models which would have never been considered or even possible before the pandemic. Most significant of all, we observed that these restaurants went an extra step to retain those experiential factors which are considered their differentiating factor of these top restaurants. 
In relation to the main results, it was observed that most restaurants in the ranking have adapted to the crisis created by the pandemic by generating new strategies to remain competitive in the market, transitioning from reactive actions to proactive strategies that exploited new opportunities and changed their ways of working. We thus conclude that technologies, such as mobile applications and social networks, are indeed an opportunity for restaurants, at least those contained in this sample.

\section{REFERENCES}

[1] Agencia EFE. 2020. Cocina peruana reacciona ante el Covid-19: menús cortos y cartas virtuales. Gestión. https://gestion.pe/economia/empresas/cocina-peruanareacciona-ante-el-covid-19-menus-cortos-y-cartas-virtuales-noticia/

[2] Álvarez, L., López, F., \& Kuhn, M. 2020. Las estrategias de marketing digital en empresas gastronómicas pymes de la localidad de Villa Ballester. Escuela de Economía y Negocios. Universidad Nacional de San Martin.

[3] Avraham, E. 2020. From 9/11 through Katrina to Covid-19: crisis recovery campaigns for American destinations, Current Issues in Tourism, 1-15.

[4] Bajwa, SS, Wang, X., Duc, AN, Chanin, RM, Prikladnicki, R., Pompermaier, LB \&, Abrahamsson, P. 2017. Start-Ups must be ready to pivot. IEEE Softw, 18-22.

[5] Byrd, K., Her, E., Fan, A., Almanza, B., Liu, Y., \& Leitch, S. 2021. Restaurants and COVID19: What are consumers' risk perceptions about restaurant food and its packaging during the pandemic? International Journal of Hospitality Management, 94, 102821, ISSN 0278-4319, https://doi.org/10.1016/j.ijhm.2020.102821.

[6] City Tasting Tours. 2020. 'Virtual Food Tour Experience', https://www.citytastingtours.com/virtual.html

[7] Diebner, R., Silliman, E., Ungerman, K., \& Vancauwenberghe, M. 2020. Adapting customer experience in the time of coronavirus. Marketing \& Sales Practice. https://beyondretail.com.au/wp-content/uploads/2020/04/Adapting-customerexperience-in-the-time-of-coronavirus.pdf

[8] Dobbs R., Manyika, J., \& Woetzel, J. 2015. No ordinary disruption: the four global forces breaking all the trends. Public Affairs, New York

[9] Dube, K., Nhamo, G., \& Chikodz, D. 2020. COVID-19 cripples global restaurant and hospitality industry. Current Issues in Tourism. https://doi.org/10.1080/13683500.2020.1773416

[10] Espinoza Espinoza, WN 2020. La influencia del marketing en la gastronomía típica de las regiones: Al rescate de nuestro sabores y saberes. E-IDEA Journal of Business Sciences, $2(8)$, $1-17$. https://revista.estudioidea.org/ojs/index.php/eidea/article/view/59 
[11] Fine Dining Lovers. 2020. Don Julio es el mejor restaurante de América Latina $2020 . \quad$ https://www.finedininglovers.com/es/noticia/latin-america-50-bestrestaurants-lista-2020

[12] Garces. M. 2021. Teaching Basque Gastronomy: From On Location to Online in Pandemic Times. Journal of Gastronomy and Tourism. https://doi.org/10.3727/216929721X16105303036490

[13] García-Álvarez, María Teresa 2013. El rol de las tecnologías de la información y comunicación en la gestión del conocimiento: un desafío estratégico en el nuevo contexto empresarial. Revista de Ciencias Sociales (Ve), XIX (2),322-333. ISSN: 13159518. Disponible en: https://www.redalyc.org/articulo.oa?id=280/28026992011

[14] Garibaldi, R. \& Pozzi, A. 2020. Gastronomy tourism and Covid-19: technologies for overcoming current and future restrictions, Tourism facing a Pandemic: from crisis to recovery, 45-52.

[15] George, G., Lakhani, K., \& Puranam, P. 2020. What has changed? The Impact of Covid Pandemic on the Technology and Innovation Management Research Agenda. Journal of Management Studies, $57 \quad$ (8), 17541758.https://doi.org/10.1111/joms.12634

[16] Gössling, S., Scott, D, \& Hall, CM 2020. Pandemics, tourism and global change: A rapid assessment of COVID-19. Journal of Sustainable Tourism, 1-20. https://doi.org/https://doi.org/10.1080/09669582.2020.1758708

[17] Green, S. 2020. Secret Ingredients: A Comparative Analysis of Fine-Dining Experience Design for Selected Michelin Star Restaurants.) (Kiatkawsin, K., \& Sutherland, I. 2020. Examining luxury restaurant dining experience towards sustainable reputation of the Michelin restaurant guide. Sustainability, 12 (5), 2134

[18] Greve, D. 2020. Sharing the table with coronavirus - stories, initiatives and dispatches from Latin American restaurants. William Reed Business Media.https://www.theworlds50best.com/stories/News/coronavirus-storiesinitiatives-and-dispatches-from-latin-american-restaurants.html

[19] Gursoy, D., \& Chi, CG 2020. Effects of COVID-19 pandemic on hospitality industry: Review of the current situations and a research agenda. Journal of Hospitality $\begin{array}{lllll}\text { Marketing } \quad \& \quad \text { Management, } & 29 & \text { (5), }\end{array}$ https://doi.org/10.1080/19368623.2020.1788231

[20] Hernández, R., \& Dancausa, M. 2018. Turismo gastronómico. La gastronomía tradicional de Córdoba (España). Estudios y Perspectivas en Turismo, 27, 413 - 430.

[21] Hoekstra, JC, Leeflang, PSH 2020. Marketing in the era of COVID-19. Ital. J. Mark, 249-260. https://doi.org/10.1007/s43039-020-00016-3

[22] Kim, J., Kim, J., \& Wangc, Y. 2021. Uncertainty risks and strategic reaction of restaurant firms amid COVID-19: Evidence from China. International Journal of Hospitality Management, 92, 102752. https://doi.org/10.1016/j.ijhm.2020.102752

[23] Lakshmi, BM, \& Shareena, P. 2020. Impact of COVID 19 on the Restaurants. 
Journal of Interdisciplinary Cycle Research, 12(8), 1327-1334, ISSN NO: 0022-1945

[24] Le, D., Scott, N., \& Lohmann, G. 2018. Applying experiential marketing in selling tourism dreams. Journal of Travel \& Tourism Marketing, 1-16. doi:10.1080/10548408.2018.1526158

[25] Macchiavelli, A. 2020. A fragmented system in the face of the crisis. Tourism facing a Pandemic: from crisis to recovery, 33-4. DOI: 10.6092/978-88-97253-04-4

[26] Mason, A., Narcum, J., \& Mason, K. 2021. Social media marketing gains importance after Covid-19. Cogent Business \& Management, 8 (1). https://doi.org/10.1080/23311975.2020.1870797.

[27] Miranda, F. J., Rubio, S., \& Chamorro, A. (2015). The Web as a Marketing Tool in the Spanish Foodservice Industry: Evaluating the Websites of Spain's Top Restaurants. Journal of Foodservice Business Research, 18(2), 146-162. doi:10.1080/15378020.2015.1029386

[28] Monllor, J., \& Altay, N. 2016. Discovering opportunities in necessity: The inverse creative destruction effect. Journal of Small Business and Enterprise Development, 23(1), 274-291.

[29] Monllor, J., \& Murphy, P. J. 2017. Natural disasters, entrepreneurship, and creation after destruction: A conceptual approach. International Journal of Entrepreneurial Behavior \& Research, 23 (4), 618-637.

[30] Nhamo, G., Dube, K., \& Chikodzi, D. 2020. Restaurants and COVID-19: A Focus on Sustainability and Recovery Pathways. Counting the Cost of COVID-19 on the Global Tourism Industry, 205-224. https://doi.org/10.1007/978-3-030-56231-1_9

[31] Norris, CL, Taylor Jr, S. \& Taylor, DC (2021), Pivot! How the restaurant industry adapted during COVID-19 restrictions. International Hospitality Review. https://doi.org/10.1108/IHR-09-2020-0052

[32] Paredes, JC, Alberca, F., Arriola, A., Avila, C., Gavidia, M., Gómez, E., Julca, E., Llontop, C., Marsano, JM, Noriega, C., \& Zapata, M. (2020). Covid-19 and tourism in Peru. Analysis and proposals towards a new scenario. Turismo y Patrimonio, 15, 11-30.

[33] Peistikou, M. 2021. Restaurants Industry in the Covid-19 Era: Challenge or Opportunity?. Kavoura, A., Havlovic, S., \& Totskaya, N. (Ed). Strategic Innovative Marketing and Tourism in the COVID-19 Era: 9th ICSIMAT Conference 2020 (153-162).

[34] Quan, Shuai \& Wang, Ning. 2004. Towards a Structural Model of the Tourist Experience: An Illustration from Food Experiences in Tourism. Tourism Management. 25. 297-305. 10.1016/S0261-5177(03)00130-4.

[35] Rather, RA 2019. Customer experience and engagement in tourism destinations: the experiential marketing perspective. Journal of Travel \& Tourism Marketing, 37(1), 15-32. doi:10.1080/10548408.2019.1686101

[36] Seyitoğlu. F., \& Ivanov, S. (2020). Service robots as a tool for physical distancing in tourism. Curr Issues Tourism

[37] Sigala, M. 2020. Tourism and COVID-19: Impacts and implications for 
advancing and resetting industry and research. Journal of Business Research, 117, 312321. https://doi.org/10.1016/j.jbusres.2020.06.015

[38] Silva, E. 2020.7 estrategias de Marketing Gastronómico para atraer más clientes. Escuela Online de Marketing Gastronómico. https://marketingastronomico.com/7-estrategias-de-marketing-gastronomico-paraatraer-mas-clientes/

[39] Taleb, NN 2008. The Black Swan: the impact of the highly improbable. Penguin Books, London

[40] Tuomi A., Tussyadiah I., Ashton M. (2021) Covid-19 and Instagram: Digital Service Innovation in Top Restaurants. In: Wörndl W., Koo C., Steinmetz JL (eds) Information and Communication Technologies in Tourism 2021, 464-475. https://doi.org/10.1007/978-3-030-65785-7_45

[41] United Nations. 2020. La COVID-19 y la transformación del turismo. Informe de políticas, 30 pp. https://www.un.org/sites/un2.un.org/files/policy_brief_covid19_and_transforming_tourism_spanish.pdf

[42] Wiedmann, K.-P., Labenz, F., Haase, J., \& Hennigs, N. 2017. The power of experiential marketing: exploring the causal relationships among multisensory marketing, brand experience, customer perceived value and brand strength. Journal of Brand Management, 25(2), 101-118. doi:10.1057/s41262-017-0061-5

[43] William Reed Business Media. 2021. Sobre nosotros. Latin America's 50 best restaurants. https://www.theworlds50best.com/latinamerica/en/about-us.html

[44] Zabin, J. 2019. Artificial intelligence: working hand in hand with hotel staff. Retrieved from https:// hoteltechnologynews.com/2019/07/artificial-intelligenceworking-hand-in-hand-with-hotel-staff/ 